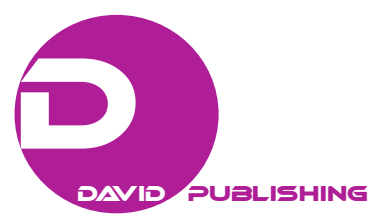

\title{
Metaphor From the Perspective of Gadamer’s Philosophical
}

\section{Hermeneutics*}

\author{
SUI Xiaoling \\ Dalian University of Technology, Liaoning, China \\ Dalian University of Foreign Languages, Liaoning, China \\ QIN Mingli \\ Dalian University of Technology, Liaoning, China
}

\begin{abstract}
As the essence of philosophical discourse, metaphor exists in various philosophical thoughts. This paper is an attempt to reveal the role that metaphor plays in the process of seeking truth, which is the ultimate goal of philosophy, by analyzing the origin of metaphor, the relationship between metaphor and philosophy as well as the use of metaphor in Gadamer's philosophical hermeneutics.
\end{abstract}

Keywords: metaphor, Gadamer, hermeneutics

\section{The Origin of Metaphor}

The study of metaphor may date back to Aristotle's On Rhetoric. In his book, metaphor has always been regarded as one of the rhetoric devices serving as a weapon of debate and praise in pulpit and public gatherings by means of an unconventional way of speaking. It is believed to increase the opportunities of winning in arguments in which words play a decisive role. Metaphor is even seen as a form of art, beautifying the plain words and turning them into a subtle speech while empowering people who master it with tremendous power. Behind the eloquence, there is a right to dominate words without any physical objects, and thus to achieve the manipulation of people with words (Ricoeur, 2007). This proves that, in Aristotle's opinion, metaphors and ordinary words are deliberately separated from each other, and this distinction stems from the clear division between the Greeks and the Gentiles in ancient Greek society. The Greeks were considered to be the general normality in society, while the Gentiles were isolated non-normality, and the general normality transcended the non-normality in every aspect. In this circumstance, the daily words in Greek are common nouns, but the metaphor and loan words are classified as uncommon nouns. Common nouns are easy to express and be understood with generality and certainty in daily communications (Chen, 2013).

In terms of what metaphor is, Aristotle made expositions about it from different perspectives in On Rhetoric and Poetics respectively, and his views were divinized as the Bible of the Western rhetorical metaphor and poetic metaphor in later years. In Poetics, Aristotle demonstrates that metaphor transfers the name of one

\footnotetext{
* Acknowledgement: Key Program of the National Social Science Fund of China (18AZW002); Research Project of Dalian University of Foreign Languages (2018XJYB36).

SUI Xiaoling, Ph.D. candidate, Faculty of Humanities and Social Sciences, Dalian University of Technology, Liaoning, China; lecturer, Department of Foreign Language Education for Non-Majors, Dalian University of Foreign Languages, Liaoning;, China.

QIN Mingli, Dr., professor, School of Foreign Languages, Dalian University of Technology, Liaoning,; China.
} 
thing into another, and the transference being either from genus to species, or from species to genus, or from species to species on the basis of analogy (Ricoeur, 2007). In other words, it can be briefly described as "giving the thing a name that belongs to something else” (Cooper, 2007, p. 10). This description basically covers most of the definitions of metaphor made by subsequent rhetoricians.

Aristotle's definition of metaphor remains at the lexical level and is completely different from the ordinary usage of words. Therefore, the use of metaphor is only confined to Aristotle's rhetoric and poetry (Aristotle, 1996), and his interpretations of metaphor is based on the similarity between the tenor and the vehicle-As a result, the cognitive functions and values included in metaphor has not been noticed.

The analytic philosophy and formalistic philosophy believe that there is no correlation between metaphor and concept, and its establishment is determined by the relationship between linguistic symbols and the objective world, in which the mind is not involved. The study of "conceptual metaphor" is proposed for the first time until the publication of Metaphors We Live By by Lakoff and Johnson in 1980. Influenced by empiricism, Lakoff and Johnson state that the philosophical enlightenment of metaphorical thinking is that physical experience is the precondition of metaphor (Wang, 2002). In other words, metaphor is the result of the combination of physical body, experience and mind. Meaning comes from the way that physical body runs itself and combines sensorimotor experience with subjective judgement. Therefore, metaphor is not what people have always believed that it has cracks that cannot be erased with reality, which means metaphor lacks reality. Whorf, an American scholar, points out that metaphor is a "confusion of thought” caused by synesthesia, and the synesthesia has its authenticity (Carrol, 1956, p. 156). Accordingly, metaphor is a combination of experience and realistic synesthesia (Liu \& Meng, 2014). It maps reasoning types from the source domain into the target domain. The abstract expositions of many subjects, including philosophy, become possible on the grounds of metaphor.

\section{Metaphor and Philosophy}

Metaphor, the mystery of languages and meanings, penetrates into every field of linguistic activities with its rich experience. It transitions from the marginal position of rhetoric in discourse to the central position of understanding the human comprehension itself, gaining unprecedented significance. Hence, it has become the unavoidable issue in philosophy, psychology, history, theology, semantics, translation studies, logics, etc. Like Laozi’s “Tao” metaphor, Plato’s “Allegory of the Cave”, Descartes' "Light Metaphor”, Marx’s "Phantom Metaphor”, and Heidegger's "Home” metaphor, all of them have built up the connotation of meaning.

The ultimate problem of metaphor is the problem among metaphor, language, and thinking. In Nietzsche's (2015) early work, On Truth and Lies in a Nonmoral Sense, he points out that metaphor is the origin of all languages and concepts, thus, every language should have the nature of metaphor. Wang Tangjia, in his article, Metaphorical Hermeneutics: Marriage of Rhetoric and Philosophy-Discourse on the Metaphor Theory of Ricoeur, also puts forward that the use of metaphor in language can best demonstrate the expansion of space in lexical meaning. Philosophy cannot be separated from words, which carries the effect of metaphor meaning (Wang, 2004). Metaphor is not only one of the rhetorical devices referring to the lexical replacement, but more importantly, a way of thinking and a cognitive method with epistemological and ontological implication. Thinking determines language and language is the external expression of thinking in that human's way of thinking is mainly metaphorical, and metaphor is the external manifestation of metaphorical thinking. 
In addition, metaphor is not only an activity closely related with understanding, but also a realistic grasp of existence. Deeply influenced by Heidegger's ontology, Gadamer's profound analysis on understanding is the necessary condition for grasping the moment. Metaphor is the disclosure of existence of being itself and preparing for a new understanding (Ding, 2012). Moreover, metaphor is a way to reveal the truth.

\section{Metaphor and Gadamer's Philosophical Hermeneutics}

In the 20th century, the development of analytic philosophy was described as a sort of "Linguistic Turn", and continental philosophy tracks this turn in the works of Husserl, Merleau-Ponty, Gadamer, and Ricoeur, especially in the Gadamer's philosophical hermeneutics work Truth and Method. Although Gadamer does not elaborate on metaphor in his writings, his in-depth discussion about words greatly inspire us to understand metaphor. Metaphor has been used repeatedly in his writings to vividly show the core position of language in his thought and to present his philosophical purport. Metaphor, with transcendent understanding and interpretation, not only contains the transition from the known to the unknown, but also means that interpretation is based upon understanding and creates new meaning in the whole process, during which the construction of meaning depends on metaphor, and understanding itself possesses linguisticality and metaphoricality in the general sense.

The play, or spiel, is crucial metaphor in Gadamer's philosophical hermeneutics and has been interpreted from different perspectives by many philosophers, such as Kant, Schiller, Spencer, Heidegger, Wittgenstein, Derrida, and so on, in the history of modern Western philosophy. However, in Truth and Method, Gadamer advances his discussion to language play as the way of having the world in linguistic field via the play as a way of existence of work of art in aesthetic field and therefore moves forward from the discussion of work of art to the discussion of the ontological shift of hermeneutics guided by language smoothly, realizing the transition from play to language play under mutual reflection. We can even believe that, in Gadamer's philosophical hermeneutics, the play of work of art is the language play and vice versa, which profoundly embodies Gadamer's philosophical theme. Taking the analysis on art experience as a start, Gadamer tries to use the metaphor, "play", to explore the hermeneutic issues on understating and truth. Understanding is a play (Gadamer, 2007a) with dialogue structure, and therefore it is a language play. "Gadamer elucidates the understanding activity as a conversational and hyper-subjective event in terms of its nature” (Gadamer, 2004, p. 19).

From Gadamer's hermeneutic perspective, the structure of play is composed of play, players, and spectators. The play is like a powerful magnetic field attracting both players and spectators, who are in the inner layer and outer layer respectively. The real subject of the play is not the players, but the play itself. The play does not refer to the players' attitudes, motions, or subjective freedom, which means subjectivity, thus regarding the play as a way to understand work of art overcomes the way of thinking of subject-object dichotomy.

The play is "an image to understand artistic experience. It specifies that people can recognize that subject-object dichotomy is not the only or the fundamental way to understand human's existence” (Johnson, 2003, p. 27). The understanding and the play share the same structure (Gadamer, 2007b). Gadamer compares the "play" to the relationship between interpretation and interpreted subjects. "How to make those things we encountered in understanding present their emphases is a language process, or a play carried on by words around its signified content” (Gadamer, 2007b, p. 659). 
Another important metaphor is dialogue, which not only facilitates interpersonal communication, but also establishes connection with history. The aim of dialogue is not only to gain an access to information and knowledge, but more importantly to broaden one's own "horizon", and to constantly integrate with the "horizon" of others, and then to reach a consensus, that is fusion of fusion (the fusion of conventional concepts and contemporary situations). The process of dialogue takes place and is presented in language, which plays a significant role in Gadamer's philosophical hermeneutics. In Gadamer's opinion, dialogue is the most basic thing as being, it is being itself. Socrates is able to discover the essence of dialogue in thought and truth as dialogue makes the distance between people disappear and overcomes the solipsism in epistemology. Just in order to overcome solipsism, Gadamer embarked on dialectics of dialogue. He said: "dialogue is a way to obtain the truth under the mutual participation of both sides" (Gadamer, 1988, p. 69).

The light metaphor is a basic one in the Western philosophy, and various philosophers have different understandings about it. Kant, in his theory of metaphysics, puts forward three concepts that are similar to what phenomenology refers to as "horizon" later and close to the platonic "light" with guidance and disclosure. Gadamer also discusses "light”. In fact, the Western traditional metaphysics is a kind of "light" metaphysics, and Western philosophy, with more than 2,000 years history, is a history of Platonism. Gadamer stands on the position of phenomenology to critically absorb the Western metaphysics of "light", emphasizing "words (Erschlossenheit)" and maintaining that "it is the light of words that enables everything to interpret itself and to understand itself” (Gadamer, 2007a, p. 616).

\section{The Significance of Metaphor in the Search for Truth}

Truth has always been a focused issue in philosophy. Three examples have been listed to illustrate the significance of revealing truth by metaphors in Gadamer's philosophical hermeneutics. First of all, metaphor reveals new meanings in a vivid way. People can achieve self-understanding better and indeed understanding facts about the world are to make the truth disclosed. Secondly, whether the play metaphor or the dialogue metaphor, it emphasizes on the importance of practice and participation. To some extent, it deepens people's understanding of the relationship between theory and practice in philosophical hermeneutics (He, 1999). Lastly, in Gadamer's philosophical hermeneutics, light metaphor embodies the methodological meaning of phenomenology. "Facing the matter itself" is based on facts, and it is helpful to overcome relativistic issues generated by historicism.

Metaphors We Live By, Lakoff and Johnson put forward a series of unique views on truth based on previous studies, form empirical truth theory, and dissect the inner links between metaphor and truth. They propose that "meaning theory and truth theory are based on understanding theory" (Lakoff \& Johnson, 2015, pp. 163-164). Heidegger also points out that what metaphor helps to improve is the meaning revealed by words, and thus the world is perceived as "illuminating, veiled, and freed". The world hides some of its faces in mystery and shows itself to us with another face (Cooper, 2007). Ricoeur believes that metaphor will be more attractive through connecting truth with language and world. Therefore, metaphor shows linguisticality and disclosure ability in the process of seeking truth.

\section{Conclusion}

Metaphor, as a special form of language, is an essential linguistic phenomenon. It employs formed experience of linguistic level to describe unformed experience systematically, expressing the meaning of the 
world, and associates meanings with the world in the process of revealing truth. Metaphor is closely related to the world we live in and is a rational form with rich imagination. Gadamer and other hermeneutical philosophers discuss metaphors in the context of ontological interpretation, which is conducive to disclosing new world and unveiling the mystery of their thoughts.

\section{References}

Aristotle. (1996). Poetics. (Z. M. Chen, Trans.). Beijing: The Commercial Press.

Carrol, J. B. (1956). Language, thought, and reality: Selected writings of Benjamin Lee Whorf. Massachusetts: MIT Press.

Chen, S. H. (2013). Aristotle's view on metaphors from cognitive metaphor perspective. Journal of Anhui University (Philosophy and Social Sciences Edition), (3), 14.

Cooper, D. (2007). Metaphor. (G. C. Guo and J. An, Trans.). Shanghai: Shanghai Science and Technology Education Publishing House.

Ding, M. (2012). Ontological interpretation of metaphor. Thinking, (6), 32.

Gadamer, H. G. (1988). Praise of theory. (Z. P. Xia, Trans.). Shanghai: SDX Joint Publishing Company.

Gadamer, H. G. (2004). Philosophical hermeneutics-Editor's introduction. (Z. P. Xia and J. P. Song, Trans.). Shanghai: Shanghai Translation Publishing House.

Gadamer, H. G. (2007a). Hermeneutics I truth and method. (H. D. Hong, Trans.). Beijing: The Commercial Press.

Gadamer, H. G. (2007b). Hermeneutics II truth and method-Appendices and supplements. (H. D. Hong, Trans.). Beijing: The Commercial Press.

He, W. P. (1999). The combination of phenomenology and dialectics in language-The analysis of the double meanings of “play-dialogue theory”. Journal of Hubei University (Philosophy and Social Sciences), (5), 52.

Johnson, P. A. (2003). On Gadamer. (W. P. He, Trans.). Beijing: Zhonghua Book Company.

Lakoff, G., \& Johnson, M. (2015). Metaphor we live by. (W. Z. He, Trans.). Hangzhou: Zhejiang University Press.

Liu, X. L., \& Meng, W. (2014). Philosophical problems in the frontier of cognitive science. Beijing: Gold Wall Press.

Nietzsche, F. (2015). On truth and lies in a nonmoral sense. Verlag: CreateSpace Independent Publishing Platform.

Ricoeur, P. (2007). The rule of metaphor. (T. J. Wang, Trans.). Shanghai: Shanghai Translation Publishing House.

Wang, T. J. (2004). Metaphorical hermeneutics: Marriage of rhetoric and philosophy-Discourse on the metaphor theory of Ricoeur. Philosophical Researches, (9), 74.

Wang, Y. (2002). The philosophical basis for cognitive linguistics. Foreign Language Teaching and Research (Bimonthly), 34(3), 82. 